Sains Malaysiana 50(2)(2021): 481-492

http://dx.doi.org/10.17576/jsm-2021-5002-19

\title{
The Effects of Acute Glucoprivation on Adrenomedullary Function in SHR and WKY Rats
}

(Kesan Deprivasi Glukosa Akut pada Fungsi Medula Adrenal pada Tikus SHR dan WKY)

\author{
Hanafi Ahmad Damanhuri*, Peter Robert Dunkley \& AnN KathleEn Goodchild
}

\begin{abstract}
We have shown previously, acute intraperitoneal administration of 2-deoxy-d-glucose (2DG) into Sprague-Dawley rats led to activation of the adrenal medulla chromaffin cells, indicated with increased protein kinase activity and increased tyrosine hydroxylase (TH) phosphorylation, as well as increased plasma adrenaline and glucose levels. Here we have used spontaneous hypertensive (SHR) and Wistar Kyoto (WKY) rats to investigate whether hypertension alters basal adrenal chromaffin cell function, or the response of these cells to acute 2DG treatment. At basal level, we found no differences in adrenal medulla TH protein, TH phosphorylation, TH activity or catecholamine levels between SHR and WKY despite a significant difference in the level of systolic blood pressure; nor were there differences in plasma catecholamine levels or blood glucose $(B G)$. Furthermore, the vehicle animals evoked no significant changes in any parameter measured in SHR, but evoked significant increases in pSer 19TH, plasma adrenaline and BG in WKY. Single episode of glucoprivation evoked increases in PKA and CDK/MAPK, pSer40TH, pSer31TH, TH activity, and plasma adrenaline and BG in SHR, and in addition evoked increases in PKC, CAMKII, and pSer19TH in WKY. These findings are significant which indicates hypertension does not impact catecholamine function in the adrenal gland. It also appears that hypertension does not alter the adrenal response to glucoprivation. The findings are also significant as WKY showed greater adrenal activation of protein kinases and TH phosphorylation in response to saline and $2 D G$ when compared to SHR and possible reasons for these findings are further discussed.
\end{abstract}

Keywords: Adrenal gland; glucoprivation; hypertension; protein kinase; tyrosine hydroxylase

ABSTRAK

Kajian kami yang lepas telah menunjukkan bahawa pemberian intraperitoneal 2-deoksi-D-glukosa (2DG) akut kepada tikus Sprague-Dawley menyebabkan pengaktifan sel kromafin dalam medula adrenal yang ditunjukkan oleh peningkatan aktiviti protein kinase, pemfosforilan tirosina hidroksilase (TH), serta aras adrenalina dan plasma glukosa. Dalam kajian ini, kami telah menggunakan tikus hipertensi spontan (SHR) dan Wistar Kyoto (WKY) untuk mengkaji sama ada hipertensi akan mengubah fungsi bes sel kromafin adrenal serta tindak balas sel-sel tersebut terhadap rawatan 2DG akut. Pada peringkat bes, didapati tiada perbezaan pada aras protein TH, pemfosforilan TH, aktiviti TH atau aras katekolamina medula adrenal antara tikus SHR dan WKY walaupun terdapat perbezaan yang signifikan pada tahap tekanan darah sistolik; serta tiada perbezaan pada aras plasma katekolamina dan glukosa darah (BG). Tiada perubahan pada sebarang parameter yang diukur pada tikus pengangkut SHR, sebaliknya, terdapat peningkatan ketara pada pSer19TH, plasma adrenalina dan BG dalam tikus pengangkut WKY. Episod tunggal deprivasi glukosa mengakibatkan peningkatan pada PKA dan CDK/MAPK, pSer40TH, pSer31TH, aktiviti TH, plasma adrenalina dan BG dalam tikus SHR; di samping meningkatkan PKC, CAMKII dan pSer19TH pada tikus WKY. Hasil ini menunjukkan bahawa hipertensi tidak memberi kesan kepada fungsi katekolamina dalam kelenjar adrenal. Hipertensi turut tidak mengubah tindak balas adrenal kepada deprivasi glukosa. Tambahan pula, tikus WKY menunjukkan pengaktifan protein kinase dan pemfosforilan TH adrenal yang lebih tinggi sebagai tindak balas kepada saline dan 2DG berbanding SHR. Faktor yang mungkin menyebabkan penemuan ini turut dibincangkan dengan lebih lanjut.

Kata kunci: Deprivasi glukosa; hipertensi; kelenjar adrenal; protein kinase; tirosina hidroksilase 


\section{INTRODUCTION}

Glucoprivation using 2DG or insulin injection both lower effective plasma glucose concentrations and evoke potent counter regulatory responses to increase glucose, including activation of the sympathoadrenal pathway leading to the release of adrenaline from the adrenal chromaffin cells (Vollmer et al. 1997). We previously investigated the adrenal consequences of an acute treatment of SpragueDawley rats with 2DG (Bobrovskaya et al. 2010). We found that adrenal chromaffin cells were activated by 2DG treatment leading to increased protein kinase activity, increased phosphorylation of $\mathrm{TH}$, the rate limiting enzyme for catecholamine synthesis, and increased plasma adrenaline and glucose all within the first hour after 2DG treatment.

Hypertension may impact basal sympathoadrenal function and there is evidence to suggest that the response to acute challenge of the sympathoadrenal system may be altered in hypertension. For example, some hypertensive groups have lower plasma adrenaline levels (Adebiyi et al. 2011), elevated plasma adrenaline responses to psychological stress (Eliasson et al. 1983) and altered blood glucose responses to hypoglycemia (Mirsky et al. 1950). Our aims are to determine if basal adrenomedullary function or its response to glucoprivation induced by 2DG are altered in hypertension.

The spontaneously hypertensive rat (SHR) (Okamoto \& Aoki 1963) is a commonly used animal model of human essential hypertension. There are reports of increased, decreased or unchanged levels of plasma catecholamines, adrenal catecholamines and adrenal TH activity in SHR compared to WKY (Grobecker et al. 1982; Kumai et al. 1994; McCarty et al. 1978; Moura et al. 2005). Such individual datum is not necessarily good measures of adrenal medullary function or sympathetic overactivity as, for example, adrenal TH activity may be reduced due to feedback inhibition by high plasma catecholamines (Dunkley et al. 2004) and plasma catecholamines may be low due to high clearance rates (Esler 2011). However, the SHR appears to have an exaggerated adrenal nerve response to mental stress and glucopenia compared to Wistar-Kyoto rats (WKY) (Zhang \& Thorén 1998) supporting the idea that the hypertensive state may impair the responsiveness of the sympathoadrenal pathway.

The first aim was to determine baseline levels of blood pressure, adrenal activation by measuring adrenal medulla protein kinase activity, TH phosphorylation and activity, and plasma catecholamines and glucose levels in SHR and WKY, in order to determine whether or not hypertension alters basal adrenal medullary function.

Our second aim was to determine the responses in these parameters to an acute single intraperitoneal injection of saline and compare this with an acute single episode of glucoprivation evoked by intraperitoneal injection of 2DG in both SHR and WKY. This would assess whether or not the adrenal response to acute stressors is impacted by hypertension.

\section{MATERIALS AND Methods}

\section{MAJOR REAGENTS}

2-DG, ethylene glycol tetraacetic acid (EGTA), ethylene diamine tetraacetic acid (EDTA), dehydroxy benzyl amine (DHBA-hydrobromide), adrenaline hydrochloride, noradrenaline bitartrate salt, methanol, Tween-20, ammonium molybate, sodium pyrophosphate, sodium vanadate, B-glycerolphosphate, microcystin, dithiothreitol (DTT), catalase, activated charcoal, reduced glutathione, and mouse anti-tyrosine hydroxylase antibody (catalogue \#T1299) were purchased from Sigma Chemical Co. (St Louis, MO, USA). Ultra-free-MC UFC30GV00" (0.22 $\mu \mathrm{m}, \mathrm{PVDF})$ centrifugal filter unit. Sodium dihydrogen orthophosphate and disodium hydrogen phosphate dodecahydrate, hydrochloric acid and glacial acetic acid were from Univar (Texas, USA). Sodium 1-Octanesulfonate was from Tokyo Chemical Industry (Tokyo, Japan). Aluminium oxide was from Wako Chemicals USA Inc (Richmond, VA, USA). Tetrahydrobiopterin was supplied by Dr. Schirck's Laboratory (Jona, Switzerland). L-tyrosine was from DBH Biochemicals (Poole, U.K.).

Optiphase HiSafe scintillation cocktail was from Perkin-Elmer (Waltham, MA). Complete tablet was from Roche (Germany). Criterion Tris-HCl precast gels $(10 \%)$ and molecular-weight PAGE standards were from Bio-Rad Laboratories (Hercules, CA, USA). 3,5-[3H]L-tyrosine, nitrocellulose membrane (Hybond ECL) and ECL Advanced kit were from GE Health Care (Little Chalfont, UK). Anti-rabbit immunoglobulin (horseradish peroxidase-linked whole antibody from goat, catalogue \#111-035-144) and anti-mouse immunoglobulin (horseradish peroxidase-linked whole antibody from goat, catalogue \#115-635-035) were from Jackson Immunoresearch Laboratories Inc. (West Grove, PA, USA). Anti-sheep immunoglobulin (horseradish peroxidaselinked whole antibody from rabbit, catalogue \#31480) was from Pierce Biotechnology (Rockford, USA). PhosphoSer40TH, phospho-Ser31TH, and phospho-Ser19TH specific antibodies were generated and tested for specificity as described by (Bobrovskaya et al. 2004; Gordon et al. 2009).

\section{ANIMALS}

All experiments were carried out on male Wistar Kyoto rats (WKY) and spontaneously hypertensive rats (SHR) (300 - 500g, $20-24$ weeks of age; $\mathrm{n}=25$ animals of 
each strain) purchased from Animal Resource Centre (Perth, Australia) with the approval of the Animal Ethics Committees of Macquarie University, Sydney and conducted in accordance with the Australian Code of Practice for the Care and Use of animals for scientific purposes.

At 20 weeks, systolic blood pressure was measured using tail cuff plethysmography. One day prior to experimentation, rats were housed singly with ad libitum access to food and water. Multiple cages were housed in a single room for a minimum of $12 \mathrm{~h}$ and rats were always within sight, sound and smell of other rats.

\section{SYSTOLIC BLOOD PRESSURE MEASUREMENT}

The NIBP Multi Channel Blood Pressure Systems (IITC Inc. Life Sciences, CA USA) was used to determine systolic blood pressure. Animals were trained in the apparatus each of the 3 days prior to the day of measurement. Animals were placed in a temperature-controlled chamber $\left(37^{\circ} \mathrm{C}\right)$ within a Perspex tube and an inflatable cuff was positioned at the base the tail. Once a stable pulse oscillation was evident, the cuff was inflated and then slowly released. The first pulse signal was correlated with the cuff pressure which was determined to be the systolic blood pressure. A minimum of 3 readings were collected and the results averaged.

\section{TREATMENT}

The basal group consisting of both SHR $(\mathrm{n}=5)$ and WKY $(\mathrm{n}=5)$, animals were sacrificed without treatment. Both SHR ( $n=10$ per treatment) and WKY $(n=10)$ were administered either saline $(0.4 \mathrm{~mL}$ i.p.) or 2DG $(400 \mathrm{mg} /$ $\mathrm{kg}, 0.4 \mathrm{~mL}$ i.p.). Food and water were then removed from the cage. Animals were sacrificed at $30 \mathrm{~min}$ following injection by an anaesthetic overdose (Lethabarb, $80 \mathrm{mg} /$ kg i.p.). Rats were decapitated by guillotine and blood and tissue samples collected.

\section{BLOOD AND TISSUE COLLECTION}

Whole trunk blood $(5 \mathrm{~mL})$ was collected into tubes containing $19 \mathrm{mg}$ EGTA and $6 \mathrm{mg}$ reduced glutathione in $200 \mu \mathrm{L}$ of water and kept cold $\left(4{ }^{\circ} \mathrm{C}\right.$ ) (Lambert et al. 1991). Blood samples were centrifuged for $10 \mathrm{~min}$ at 1800 $\mathrm{rpm}\left(4{ }^{\circ} \mathrm{C}\right)$. Resulting plasma was then spun for $10 \mathrm{~min}$ at $2700 \mathrm{rpm}\left(4{ }^{\circ} \mathrm{C}\right)$. Plasma samples were kept at $-80{ }^{\circ} \mathrm{C}$ until further analysis.

Whole adrenals were removed and dissected, to obtain fresh adrenal medulla for the TH activity analyses, prior to freezing for the analysis of cell signalling substrates. Whole adrenals were rapidly frozen in dry ice and kept at $-80{ }^{\circ} \mathrm{C}$ until used for measurement of $\mathrm{TH}$ phosphorylation or the adrenal content of catecholamines.
MEASUREMENT OF PHOSPHO-CAMKII, PHOSPHO-PKA, PHOSPHO-PKC, PHOSPHO-MAPK/CDK SUBSTRATES IN

\section{THE ADRENAL MEDULLA}

Adrenal medulla was weighed and homogenised in 40 volumes of homogenization buffer ( $2 \%$ SDS, 2 mM EDTA, $50 \mathrm{mM}$ Tris $(\mathrm{pH} 6.8)$ by sonication on ice $(3$ times $\times 30$ $\mathrm{s}$ at $10,000 \mathrm{~A}$ ), then boiled for $5 \mathrm{~min}$ and centrifuged for $20 \mathrm{~min}$. Supernatants were removed carefully. Protein concentration was determined by BCA protein assay kit (Thermo Fisher Scientific, IL, USA). $100 \mu \mathrm{L}$ of supernatant were mixed with $5 \mu \mathrm{L}$ of $10 \%$ dithiothreitol (DTT) and $35 \mu \mathrm{L}$ of sample buffer ( $40 \%$ glycerol, $50 \mathrm{mM}$ Tris, minimal bromophenol blue, $\mathrm{pH}$ 6.8) to make up the final protein concentration $2 \mu \mathrm{g} / \mu \mathrm{L}$ in each sample. $30 \mu \mathrm{g}$ from each sample was run on $10 \%$ Criterion Tris$\mathrm{HCl}$ precast gels and then transferred to nitrocellulose as described (Bobrovskaya et al. 2010). Membranes were immunoblotted with primary antibodies against phospho CaMKII antibody (catalogue \#06-881) or rabbit anti-pan CaMKII antibody (catalogue \#07- 1496) from Milipore (Billerica, MA USA) or phospho-PKA substrates (catalogue \#9621), phospho-PKC substrates (catalogue \#2261), phospho-MAPK/CDK substrates (catalogue \#2321) acquired from Cell signaling Technology, MA, USA and utilised according to the manufacturer's instructions.

Secondary antibodies (goat anti-rabbit and goat antimouse immunoglobulin) were applied to the membranes for $1 \mathrm{~h}$ at room temperature. The immunoblots were visualized and quantified on the LAS4000 imaging system (GE Health Care, Little Chalfont, UK) using ECL-advanced detection reagent (GE Health Care, Little Chalfont, UK). The analysis on protein band density was determined by selecting the whole lane from each sample. All analysis was done using Fujifilm Multigauge v3.0 software (Tokyo, Japan). The density of the bands was measured and expressed as a fold increase relative to basal. The loading controls were performed by analysis of the total CaMKII and $\beta$-actin protein.

\section{SITE-SPECIFIC TH PHOSPHORYLATION AND TH PROTEIN IN WHOLE ADRENAL GLAND}

Whole adrenals were processed, run on SDS-PAGE and transferred to nitrocellulose as described earlier Membranes were immunoblotted with total or phosphospecific $\mathrm{TH}$ antibodies for $1 \mathrm{~h}$ at room temperature or overnight at $4{ }^{\circ} \mathrm{C}$. The levels of pSer19TH, pSer31TH, pSer40TH, total $\mathrm{TH}(\mathrm{tTH})$ protein and $\beta$-actin protein were determined using specific antibodies all of which have been characterized previously (Bobrovskaya et al. 2004; Gordon et al. 2009). Secondary antibodies (goat anti-rabbit, goat anti-mouse or rabbit anti-sheep immunoglobulin) were applied to the membranes for $1 \mathrm{~h}$ at room temperature. The immunoblots were visualized and 
quantified on the LAS4000 imaging system (GE Health Care, Little Chalfont, UK) using ECL-advanced detection reagent (GE Health Care, Little Chalfont, UK). The density of the bands was measured by selecting the specific area of the protein band and subtracting the background. All analysis was done using Fujifilm Multigauge v3.0 software (Tokyo, Japan) and expressed as a fold increase relative to basal. The loading controls were performed by analysis of the total $\mathrm{TH}$ protein and $\beta$-actin protein. Sitespecific TH phosphorylation was expressed as the ratio of TH phosphorylation at Ser19, Ser31 or Ser40 to total $\mathrm{TH}$ protein, to account for variability in total $\mathrm{TH}$ protein between samples. Total TH protein levels were expressed as the ratio of $\mathrm{TH}$ protein to $\beta$-actin as $\beta$-actin levels are largely invariable and commonly used as a housekeeping protein.

\section{ADRENAL MEDULLA TH ACTIVITY ASSAY}

Samples were homogenised in homogenization buffer (60 $\mu \mathrm{L}, 2$ mM Kphos buffer pH 7.4, 1 mM EGTA pH 7.5, $1 \times$ protease inhibitor cocktail tablet, $1 \mathrm{mM}$ DTT, $80 \mu \mathrm{M}$ ammonium molybate, $1 \mathrm{mM}$ sodium pyrophosphate 1 $\mathrm{mM}, 1 \mathrm{mM}$ sodium vanadate, $5 \mathrm{mM} \beta$-glycerolphosphate and $2 \mu \mathrm{M}$ microcystin). Samples were sonicated 3 times $\times$ $30 \mathrm{~s}$ at $4{ }^{\circ} \mathrm{C}$, using a micro-sonicator, and then centrifuged for $20 \mathrm{~min}$ at $16,000 \mathrm{rpm}$. Supernatants were collected and protein levels were determined using a BCA protein assay kit (Thermo Fisher Scientific, IL, USA) according to the manufacturer's instructions. TH activity was measured using a method based on the tritiated water release assay with minor modifications (Reinhard et al. 1986). The reaction mixture contained $50 \mu \mathrm{g}$ sample, $36 \mu \mathrm{g}$ catalase, $2 \mathrm{mM}$ potassium phosphate $(\mathrm{pH} 7$ - 7.4), $0.008 \% \beta$-mercaptoethanol, $24 \mu \mathrm{M}$ tyrosine, $1 \mu \mathrm{Ci}$ $3,5-[3 \mathrm{H}]$ tyrosine and $100 \mu \mathrm{M}$ tetrahydrobiopterin, final volume $50 \mu \mathrm{L}$. Assays were performed for $20 \mathrm{~min}$ at 30 ${ }^{\circ} \mathrm{C}$ and were stopped by addition of $700 \mu \mathrm{L}$ charcoal slurry (7.5\% activated charcoal in $1 \mathrm{M} \mathrm{HCl}$ ). Unbound ${ }^{3} \mathrm{H}_{2} \mathrm{O}$ was analysed by scintillation spectrometry (Wallac1410, Pharmacia, Turko, Finland) for 20 min per sample.

\section{ADRENAL GLAND AND PLASMA CATECHOLAMINE \\ CONTENT AND BLOOD GLUCOSE MEASUREMENTS}

For the adrenal gland catecholamine content analysis, the whole gland was homogenized in 40 volumes of $0.2 \mathrm{M}$ perchloric acid, sonicated 3 times $(30 \mathrm{~s}$ each time with samples constantly on ice) and centrifuged for $15 \mathrm{~min}$ at $20,000 \times \mathrm{g}\left(4{ }^{\circ} \mathrm{C}\right) .500 \mu \mathrm{L}$ of resulting supernatant was used for the analysis and catecholamine content was extracted and measured as described. The amount of adrenal gland catecholamine content was expressed per $\mathrm{mL}$ of homogenized supernatant.
Plasma catecholamines were extracted using the alumina extraction procedure with slight modifications as described previously (Anton \& Sayre 1962). Briefly, $500 \mu \mathrm{L}$ of plasma was placed into a $2 \mathrm{~mL}$ tube containing $30 \mathrm{mg}$ of activated alumina, $1 \mathrm{~mL}$ of $1.5 \mathrm{M}$ Tris buffer (pH 8.6), $100 \mu \mathrm{L}$ of $0.1 \mathrm{M}$ disodium EDTA and $0.5 \mathrm{ng}$ of 3,4-Dihydroxybenzylamine (DHBA) which was used as an internal standard.

This was mixed gently for $10 \mathrm{~min}$ and washed 3 times using $1 \mathrm{~mL}$ of deionized water. The catecholamine was collected by extraction using an elution solution of $200 \mu \mathrm{L}$ of $2 \%$ acetic acid containing $100 \mu \mathrm{M}$ disodium EDTA. Measurement of plasma adrenaline (Adr) and noradrenaline (NAdr) was performed using HTEC-500 Complete Stand-Alone HPLC-ECD systems (Eicom Corporation, Kyoto Japan). Analytical conditions were as follows: Detector, $+450 \mathrm{mV}$ potential against an $\mathrm{Ag} / \mathrm{AgCl}$ reference electrode; column, Eicompak CA-5ODS, $2.1 \times$ $150 \mathrm{~mm}$; mobile phase, $0.1 \mathrm{M}$ phosphate buffer ( $\mathrm{pH}$ 5.7) containing $50 \mathrm{mg} / \mathrm{L}$ disodium EDTA, $700 \mathrm{mg} / \mathrm{L}$ sodium 1-octanesulfonate, and $12 \%$ methanol at a flow of 0.23 $\mathrm{mL} / \mathrm{min}$. The specific retention time for each compound was determined using adrenaline and noradrenaline standards. The amount of catecholamine from each sample was calculated from the peak height ratio relative to DHBA using PowerChrom v2.6.3 software (eDAQ Pty Ltd, NSW Australia). Blood glucose was measured using Accu-check performa glucometer from Roche (Mannheim, Germany).

\section{STATISTICAL ANALYSES}

The basal levels of each of the parameters investigated were initially compared between the SHR and WKY animals using unpaired T-tests. Statistical analyses were then performed using one-way ANOVA to compare between the basal, saline and 2DG groups within each strain. Differences were considered to be significant at the $\mathrm{p}<0.05$ level.

\section{RESULTS}

\section{BASAL MEASUREMENTS COMPARING THE SHR AND WKY} ANIMALS

The levels of the major parameters investigated were compared between the SHR and WKY under basal conditions. Table 1 shows that prior to treatment, the only measurable difference between SHR and WKY was that the systolic blood pressure in the SHR was significantly increased. There was no significant difference in the adrenal medulla levels of TH protein, TH phosphorylation, TH activity or the adrenal content of adrenaline or noradrenaline between SHR and WKY before treatment. There was also no significant difference in the pretreatment plasma levels of adrenaline, noradrenaline or blood glucose between SHR and WKY. 
TABLE 1. Comparison of SHR and WKY under basal (untreated) conditions. The levels of adrenal medulla TH protein and $\mathrm{TH}$ phosphorylation were determined using western blotting and typical blots of basal samples are shown in Figures 2 and 3. The levels of TH protein were corrected for beta actin levels in each sample prior to averaging and the levels of TH phosphorylation at Ser40, 31 and 19 were corrected for TH protein in each sample prior to averaging. TH activity, adrenaline (Adr) and noradrenaline (NAdr) were also determined as were the levels of plasma adrenaline and noradrenaline, glucose and sBP. *indicates a significant difference between groups: ${ }^{*} p<0.05$

\begin{tabular}{lcc}
\hline & SHR $(\mathrm{n}=5)$ & WKY $(\mathrm{n}=5)$ \\
\hline Systolic pressure $(\mathrm{mmHg})$ & $195 \pm 6^{*}$ & $122 \pm 2$ \\
Adrenal gland & & $1.00 \pm 0.08$ \\
TH protein/ $\beta$-actin & $1.22 \pm 0.14$ & $1.00 \pm 0.18$ \\
pSer40TH/tTH & $0.79 \pm 0.05$ & $1.00 \pm 0.31$ \\
pSer31TH/tTH & $0.98 \pm 0.15$ & No data available \\
pSer19TH/tTH & No data available & $1.10 \pm 0.060$ \\
TH activity & $1.0 \pm 0.044$ & $41.1+2.7$ \\
Adrenaline $(\mathrm{ng} / \mathrm{mL})$ & $42.8 \pm 1.9$ & $12.2 \pm 1.1$ \\
Noradrenaline $(\mathrm{ng} / \mathrm{mL})$ & $14.1 \pm 1.4$ & \\
SHR & & $1.015 \pm 0.155$ \\
Adrenaline $(\mathrm{ng} / \mathrm{mL})$ & $1.001 \pm 0.408$ & $0.150 \pm 0.032$ \\
Noradrenaline $(\mathrm{ng} / \mathrm{mL})$ & $0.146 \pm 0.029$ & $8.0 \pm 0.3$ \\
Glucose $(\mathrm{mMol} / \mathrm{L})$ & $8.7 \pm 0.3$ & \\
\hline
\end{tabular}

\section{THE EFFECTS OF 2DG ON SYSTOLIC BLOOD PRESSURE IN THE SHR AND WKY ANIMALS}

The systolic blood pressure was measured in each group of animals undergoing saline or 2DG treatment (saline SHR vs WKY $183 \pm 2$ vs $124 \pm 3, \mathrm{p}<0.05$ : 2DG SHR vs WKY 179 \pm 7 vs $133 \pm 4, \mathrm{p}<0.05)$. These levels were not significantly different to those in the respective basal group.

\section{THE EFFECTS OF 2DG ON PROTEIN KINASE ACTIVITY IN THE ADRENAL MEDULLA OF SHR AND WKY}

The stress of handling animals and injection of saline could lead to activation of adrenal medullary cells. Therefore, we sought to determine whether substrates phosphorylated by protein kinase A (PKA), protein kinase $\mathrm{C}$ (PKC), the proline directed protein kinases CDK and MAPK (CDK/MAPK) and Ca2+/calmodulin-dependent kinase II (CaMKII) were altered in SHR or WKY animals following saline treatment (Figure 1). There was no significant difference in substrate phosphorylation for any of these protein kinases between the basal (untreated) animals and the saline treated animals for either SHR or WKY (Figure 1(A)-1(D)).

Treatment with 2DG significantly increased the phosphorylation of PKA substrates in SHR and WKY relative to both untreated and saline treated animals $(p<0.05$, Figure 1(E)). Treatment with 2DG had no effect on the phosphorylation of PKC substrates in SHR, while significant increases were seen in WKY relative to both untreated and saline treated animals $(\mathrm{p}<0.05$, Figure $1(\mathrm{~F})$ ). Treatment with 2DG significantly increased the phosphorylation of CDK/MAPK substrates in SHR relative to both untreated and saline treated animals $(\mathrm{p}<0.001)$, while a significant increase was only seen in WKY relative to saline treatment $(p<0.05$, Figure $1(G)$ ). Treatment with 2DG had no effect on CAMKII phosphorylation in SHR, while a significant increase was only seen in WKY relative to untreated animals $(\mathrm{p}<0.05$, Figure 1(H)).

\section{THE EFFECTS OF 2DG ON PHOSPHORYLATION OF TH AT SER19, 31 AND 40 AND TH PROTEIN LEVELS IN THE ADRENAL GLAND OF SHR AND WKY}

As $\mathrm{TH}$ is only present in the adrenal medulla and not the adrenal cortex, then, measuring TH phosphorylation and $\mathrm{TH}$ protein levels in the whole adrenals means that we were actually measuring responses that occurred in the adrenal medullary cells. Representative images from western blot analysis are shown from SHR and WKY for each of the antibodies used (Figure 2(A)). Total TH protein levels were not different in the adrenal glands of SHR or WKY after either saline or $2 \mathrm{DG}$ treatments relative to 
untreated animals (not shown). There was no significant difference between the basal (untreated) animals and the saline treated animals for SHR or WKY for any of the TH phosphorylation sites measured, except that pSer19TH was increased in WKY (Figure 2(B)-2(D)).

Treatment with 2DG significantly increased pSer40TH in SHR relative to saline treatment, while a significant increase was seen in WKY relative to untreated and saline treated animals (Figure 2(B)). Treatment with 2DG significantly increased pSer31TH in both SHR and WKY relative to untreated and saline treated animals (Figure 2(C)). Treatment with 2DG had no effect on pSer19 in SHR, while significant increases were seen in WKY relative to both untreated and saline treated animals (Figure 2(D)).

\section{THE EFFECTS OF 2DG ON TH ACTIVITY IN THE ADRENAL GLAND OF SHR AND WKY}

Saline treatment did not alter TH activity in SHR or WKY compared to untreated animals (Figure 3). 2DG treatment significantly increased TH activity in both WKY and SHR relative to untreated and saline treated animals.

\section{THE EFFECTS OF 2DG ON PLASMA CATECHOLAMINES AND BLOOD GLUCOSE IN WKY AND SHR}

There were no significant differences between the basal (untreated) animals and the saline treated animals for either SHR or WKY for plasma adrenaline or noradrenaline (Figure 4), except that saline treatment significantly increased adrenaline levels in WKY. Treatment with 2DG significantly increased plasma adrenaline and noradrenaline in SHR and WKY relative to untreated animals.

Treatment with 2DG significantly increased plasma glucose in both SHR (and WKY) relative to saline treatment (SHR 2DG vs saline 19.7+0.7vs9.5+0.2mMol/1, $\mathrm{p}<0.05$; WKY 2DG vs saline 20.1+1.0vs $12.2+0.7 \mathrm{mMol} / 1, \mathrm{p}<0.05$ ). Saline treatment also significantly increased plasma glucose in WKY relative to SHR $(\mathrm{p}<0.05)$.

A

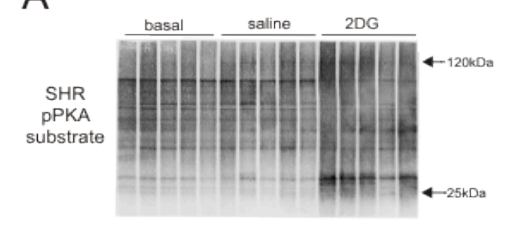

B
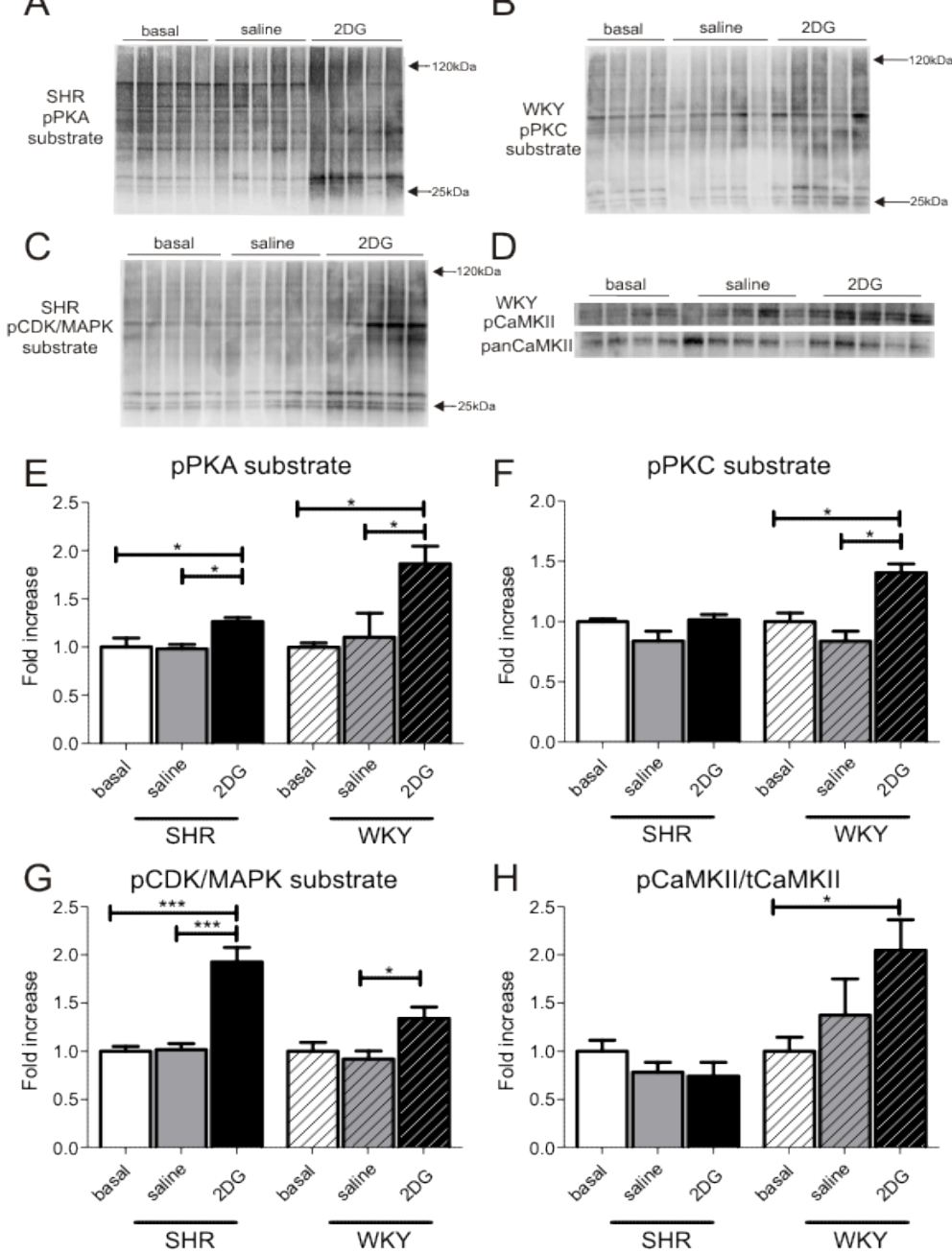

FIGURE 1. Change in phosphorylation of (A, E) PKA, (B, F) PKC, and (C, G) CDK/MAPK substrates, and (D, H) CAMKII phosphorylation in the adrenal medulla thirty min following saline (grey bars) or 2DG treatment (black bars) compared to basal conditions (clear bars-set to 1.0) in SHR (solid bars, $\mathrm{n}=5$ for each group) and WKY (hatched bars, $n=5$ for each group).A-D) Examples of western blots used in the analysis with two molecular weight markers indicated. A) PKA substrates B) PKC substrates, C) CDK/MAPK substrates and D) phosphoCAMKII. *indicates a significant difference between groups: $* \mathrm{p}<0.05, * * * \mathrm{p}<0.001$ 
A

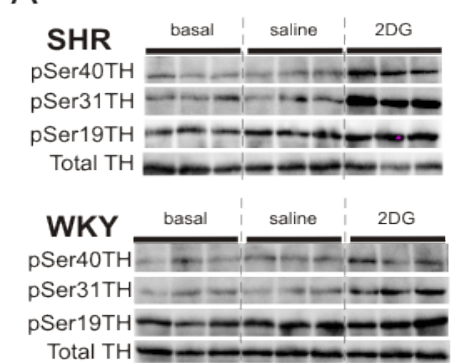

C

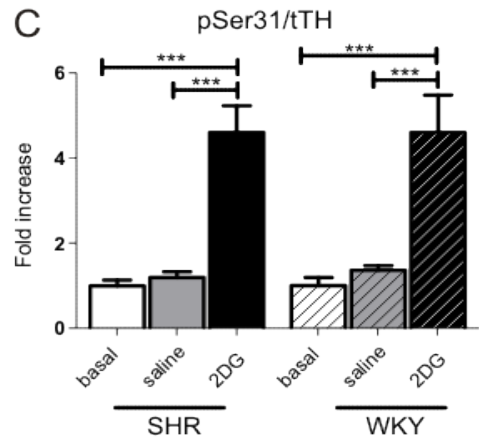

B

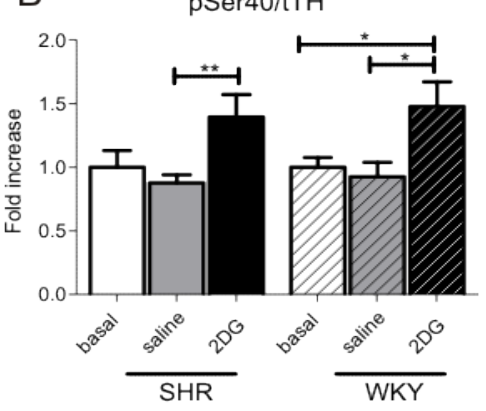

D

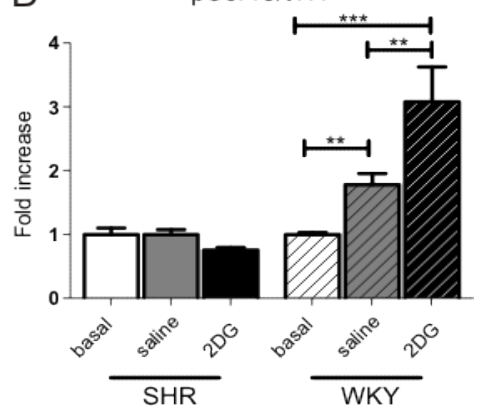

FIGURE 2. Change in phosphorylation of Ser40, Ser31, and Ser19 of TH in the adrenal gland thirty min following saline (grey bars) or 2DG treatment (black bars) compared to basal conditions (clear bars-set to 1.0) in SHR (solid bars, $\mathrm{n}=5$ for each group) and WKY (hatched bars, $\mathrm{n}=5$ for each group). A) Examples of western blots used in the analysis in SHR and WKY), B) changes in pSer40TH with respect total TH (tTH), C) changes in pSer31TH with respect total TH (tTH), and D) changes in pSer19TH with respect total TH (tTH). *indicates a significant difference between groups: ${ }^{*} \mathrm{p}<0.05,{ }^{* *} \mathrm{p}<0.01, * * \mathrm{*}<0.001$

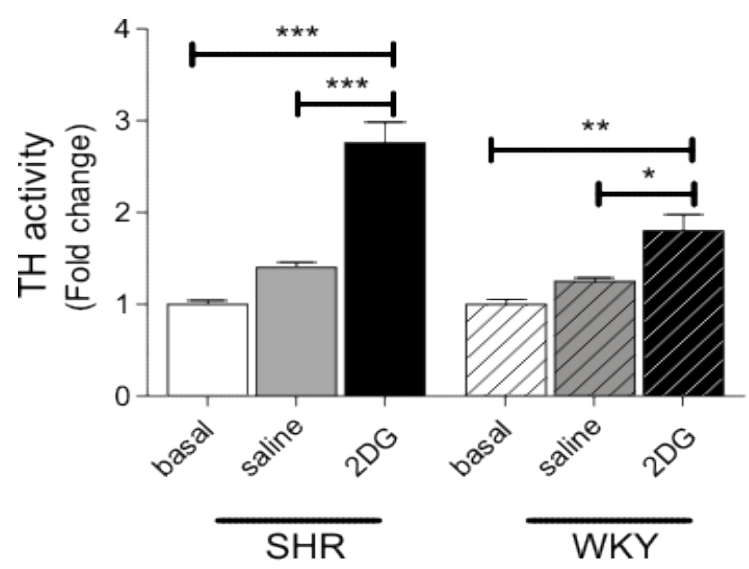

FIGURE 3. Tyrosine hydroxylase (TH) activity in the adrenal gland thirty min following saline (grey bars) or 2DG (black bars) administration compared to basal (clear bars-set to 1) in SHR (solid bars) and WKY (hatched bars). *indicates a significant difference between groups: ${ }^{*} \mathrm{p}<0.05,{ }^{* *} \mathrm{p}<0.01,{ }^{* * *} \mathrm{p}<0.001$ 

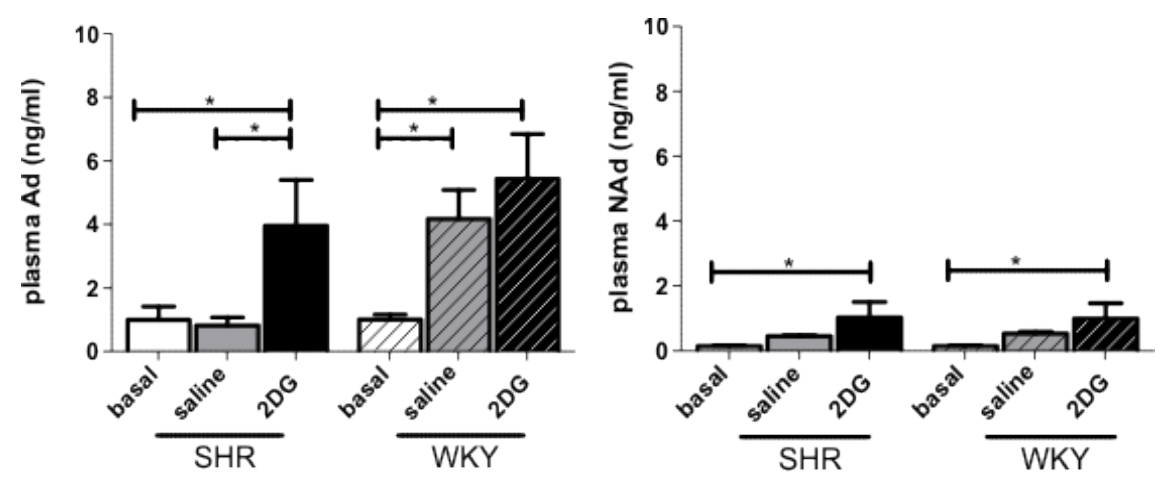

FIGURE 4. Plasma adrenaline (Adr, A) and noradrenaline (NAdr, B) thirty min following saline (grey bars) or 2DG (black bars) administration compared to basal (clear bars-set to 1) in SHR (solid bars) and WKY (hatched bars). *indicates a significant difference between groups: *p $<0.05$

\section{DISCUSSION}

The major findings in this study were that: Prior to treatment there were no differences in adrenal medulla TH protein, TH phosphorylation, TH activity or catecholamine levels between SHR and WKY despite a significant difference in the level of systolic blood pressure; nor were there differences in plasma catecholamine levels or blood glucose, saline injection evoked no significant changes in any parameter measured in SHR, saline injection evoked significant increases in pSer19TH, plasma Adr and blood glucose in WKY, a single episode of glucoprivation evoked increases in PKA, CDK/MAPK, pSer40TH, pSer31TH, TH activity, plasma adrenaline and blood glucose in SHR, a single episode of glucoprivation evoked increases in PKA, CDK/MAPK, PKC, CAMKII, pSer40TH, pSer31TH, pSer19TH, TH activity, plasma adrenaline and blood glucose in WKY. These findings indicate that hypertension does not impact catecholamine function in the adrenal gland or plasma catecholamines under basal (untreated) conditions. The SHR showed no adrenal response to intraperitoneal injection of saline, while the WKY did. Although the SHR and WKY showed overall similar responses to 2DG, the response to glucoprivation in WKY showed additional activation of protein kinases and TH phosphorylation at Ser19.

The untreated SHR and WKY differed only in that SHR had significantly elevated blood pressure. This suggests that hypertension per se did not alter the status of the animals' adrenal medulla in terms of TH phosphorylation and activation, or the content of adrenaline and noradrenaline; nor did hypertension alter the untreated animals' plasma levels of adrenaline, noradrenaline or blood glucose. This is in keeping with previous measurements of adrenal nerve activity and adrenal nerve range (Zhang \& Thorén 1998), plasma catecholamines (McCarty et al. 1978) and calcium currents in adrenal chromaffin cells (Segura-Chama et al. 2011) which under untreated conditions did not differ between SHR and WKY. However, the results are inconsistent with the findings of others who demonstrated increases in $\mathrm{TH}$ mRNA, TH activity and TH protein (Kumai et al. 1994) or decreases in TH activity and protein (Moura et al. 2005) in SHR compared to WKY. The SHR is a well-accepted as a model of essential hypertension as it demonstrates many characteristics of the human disorder including age-related increases in blood pressure and sympathetic overactivity (Doggrell \& Brown 1998; Komanicky et al. 1982; Mozaffari et al. 1996; Norman Jr. \& Dzielak 1986; Wexler 1980). Evidence of sympathetic overactivity was not represented by increased plasma noradrenaline levels in the present study, however, this is not commonly associated with increases in blood pressure in human hypertension (Esler 2011). Overall, these data suggest that any increase in sympathoadrenal function under basal conditions is counterbalanced by other mechanisms, or alternatively, there is no increase in sympathoadrenal function in hypertension.

The level of phosphorylation of PKA, PKC or CDK/ MAPK substrates, or CAMKII phosphorylation, provides an indication of the activity of these protein kinases in the adrenal medullary cells 30 min after treatment was initiated. Saline treatment failed to alter the activity of any of these protein kinases relative to untreated animals in both SHR and WKY. This suggests that at this time there was no increase above basal activity of the adrenal medullary cells. 
2DG treatment increased the activity of PKA and CDK/MAPK, but not the activity of PKC and CAMKII, in SHR relative to untreated and to saline treated animals. This suggests that after $30 \mathrm{~min}$, the adrenal medullary cells had been activated by $2 \mathrm{DG}$ treatment. An increase in protein kinase activity occurs as a result of increased levels of second messengers, such as calcium and cyclic AMP, induced by receptor and or ion channel activation. The most likely cause of this is increased splanchnic nerve activity leading to the release of neurotransmitters which bind to receptors on the adrenal medullary cells (Yamaguchi 1992). The frequency of splanchnic nerve firing alters the mix of neurotransmitters released onto medullary cells (Haycock \& Wakade 1992) and this in turn would alter the extent of medullary cell activation and the timing of protein kinase activation (Dunkley et al. 2004). The fact that the calcium-dependent protein kinases, PKC, and CAMKII, were not activated in SHR suggests that either calcium levels were not raised in response to splanchnic nerve activation, or that the effects of raised calcium were already over by $30 \mathrm{~min}$. In our previous study using Sprague Dawley (SD) rats (Bobrovskaya et al. 2010), we found increased activity of PKA 20 and 60 min after treatment with 2DG, relative to saline treatment, and increased activity of CDK/MAPK $60 \mathrm{~min}$ after 2DG treatment; there was no increase in PKC observed at either time. These results suggest that SHR responded to 2DG in the same manner as SD animals leading to essentially the same profile of activated protein kinases.

2DG treatment increased the activity of PKA, PKC, and CAMKII in WKY relative to untreated animals and increased the activity of PKA, PKC, and CDK/MAPK relative to saline treated animals. The WKY animals showed greater fold increases in PKA, PKC, and CAMKII activity, suggesting that calcium and cyclic AMP were increased to a greater extent in WKY adrenals than in SHR after $30 \mathrm{~min}$. However, the SHR animals showed a greater fold increase in CDK/MAPK activity, suggesting that this pathway was increased to a greater extent in SHR adrenals than in WKY after $30 \mathrm{~min}$. In adrenal medullary cell cultures, PKA, PKC, and CAMKII are activated more rapidly than MAPK which was only increased after 30-60 min in response to acetylcholine and PACAP (Bobrovskaya et al. 2007; Dunkley et al. 2004), the major neurotransmitters released from the splanchnic nerve at the adrenal medulla cells (Guo \& Wakade 1994). The basis of the differences in adrenal protein kinase activation between the SHR and WKY animals must relate to differences in the frequency of firing of the splanchnic nerve in response to 2DG (Niijima 1975), to differences in the capacity of the adrenal medullary cells to respond to receptor activation, or to differences in the timing of protein kinase activation. It is clear that the resting level of blood pressure is not responsible for the differences in adrenal activation between SHR and WKY animals as SD animals are also normotensive and yet they respond in the same way as SHR (Bobrovskaya et al. 2010).

$\mathrm{TH}$ is present in the adrenal medullary cells. TH protein levels were not altered by either saline or 2DG treatments $30 \mathrm{~min}$ after injection and similar results were found in SD rats after $20 \mathrm{~min}$ and $60 \mathrm{~min}$ (Bobrovskaya et al. 2010). However, 2DG treatment, but not saline treatment, was able to increase $\mathrm{TH}$ protein levels after $24 \mathrm{~h}$ in SD. These results indicate that it takes time to alter $\mathrm{TH}$ protein levelsin response to 2DG, presumably because medullary cell activation eventually leads to TH mRNA and only then to TH protein synthesis. Clearly a single episode of glucoprivation induced by 2DG is a potent activator of adrenal medullary cells relative to saline treatment and its effects at least in terms of protein production can take some time to become measurable.

TH phosphorylation at Ser40 occurs in response to a range of protein kinases in vitro including PKA, PKC, and CAMKII (Dunkley et al. 2004; Haycock 1996, 1993). 2DG treatment increased pSer40TH in SHR after 30 min relative to saline treatment and also increased PKA activity, but not PKC or CAMKII activity. Identical results were found at both 20 and $60 \mathrm{~min}$ in SD animals (Bobrovskaya et al. 2010). 2DG treatment also increased pSer40TH in WKY after $30 \mathrm{~min}$ relative to untreated and saline treated animals and PKA, PKC, and CAMKII were all increased. It is likely that PKA is responsible for TH phosphorylation at Ser40 in both SHR and WKY, with PKC, and CAMKII also contributing in WKY. TH phosphorylation at Ser31 occurs only in response to MAPK in adrenal medullary cells in vitro (Haycock et al. 1992). 2DG treatment increased pSer31 in SHR and WKY animals after $30 \mathrm{~min}$ and also increased CDK/MAPK activity at this time. Similar results were found at $20 \mathrm{~min}$ and 60 min in SD animals (Bobrovskaya et al. 2010). TH phosphorylation at Ser19 occurs primarily in response to CAMKII in vitro (Campbell et al. 1986; Dunkley et al. 2004). 2DG treatment did not increase pSer19 in SHR nor did it increase CAMKII activity. Similarly, there were no changes in pSer19TH in SD animals in response to 2DG treatment at either 20 or $60 \mathrm{~min}$ (Bobrovskaya et al. 2004). However, in WKY 2DG treatment increased Ser19 phosphorylation relative to untreated animals and also increased CAMKII. These results are also consistent with the adrenals in SHR (and SD) being less activated than those in the WKY animals. Overall, the changes in TH phosphorylation in SHR were very similar to those found in SD animals, but there were some differences in the WKY animals. These differences cannot be attributed to differences in resting levels of blood pressure.

TH is activated by phosphorylation at Ser40 and to a lesser extent at Ser31 (Dunkley et al. 2004). 2DG 
treatment increased TH activity in both WKY and SHR and this was most likely due to the increases in phosphorylation of Ser40 and Ser31 observed in both species. Although there are differences in Ser19 phosphorylation between the species in response to 2DG this was unlikely to contribute to differences in TH activation as Ser19 phosphorylation cannot directly activate TH (Dunkley et al. 2004).

Most plasma adrenaline comes from the adrenal medulla and 2DG treatment increased plasma adrenaline in SHR and WKY animals after $30 \mathrm{~min}$. This result is consistent with the observed increase in activation of the adrenal gland and the increase in activity of $\mathrm{TH}$ which would be available to synthesize new catecholamines to replace those which were secreted. It is well established that 2DG increases plasma catecholamines, primarily plasma adrenaline, in a number of species (Bobrovskaya et al. 2010; Goldstein et al. 1992; Matsunaga et al. 1989; Scheurink \& Ritter 1993). 2DG also evoked an increase in plasma noradrenaline in SHR and WKY as has been described previously in other rat strains (Bobrovskaya et al. 2010; Dronjak et al. 2004; Scheurink \& Ritter 1993). This most likely arises from noradrenaline spill over in part from the activation of sympathetic inputs to the liver (Brodows et al. 1975). The increased plasma noradrenaline secreted in response to 2DG in SHR and WKY suggests that noradrenaline spill over arises from activated sympathetic nerve terminals.

2DG treatment increased plasma glucose levels in both WKY and SHR as has been described consistently for many species (Bobrovskaya et al. 2010; Goldstein et al. 1992; Matsunaga et al. 1989; Scheurink \& Ritter 1993) and results in part from the increased plasma adrenaline, but also from activation of pathways resulting in glucagon release and subsequent glycogenolysis.

\section{CONCLUSION}

In conclusion, as the only difference identified between the untreated SHR and WKY was the level of systolic blood pressure the function of the adrenal medulla appears unaffected by hypertension. 2DG activated the adrenal medullary cells similarly in SHR and WKY. These effects were most likely evoked by activation of PKA and CDK/ MAPK which in turn activated pSer40TH and pSer31TH, respectively, which then increased the activation of $\mathrm{TH}$ in order to support the new synthesis of adrenaline to replace that released by the stimulus. As PKC, CAMKII, and pSer19TH were additionally activated by 2DG in the WKY this suggests that this strain is more sensitive to $2 \mathrm{DG}$ or the response has a different time course. As the response of SHR to $2 \mathrm{DG}$ is almost identical to that described in the normotensive SD (Bobrovskaya et al. 2010), it appears that the presence of hypertension does not alter the adrenal response to glucoprivation. The findings from this study may implicate future research on SHR and WKY, and careful consideration must be made, especially for the study that involves the adrenomedullary response.

\section{ACKNOWLEDGEMENTS}

The authors would like to thank Dr Lin Ong and Assoc. Prof Philip Dickson for their contribution. This project is funded by the Fundamental Research Grant Scheme (FRGS/2/2013/SKK01/UKM/03/4) from the Ministry of Higher Education, Malaysia, the Hunter Medical Research Institute, the NHMRC (\#1028183 and \#1030301), the ARC (DP120100920), the National Heart Foundation (G09S4340) and Hillcrest (Perpetual Trustees). The funders had no role in study design, data collection and analysis, decision to publish, or preparation of the manuscript.

\section{REFERENCES}

Adebiyi, A.A., Akinosun, O.M., Nwafor, C.E. \& Falase, A.O. 2011. Plasma catecholamines in Nigerians with primary hypertension. Ethnicity \& Disease 21(2): 158-162.

Anton, A.H. \& Sayre, D.F. 1962. A study of the factors affecting the aluminum oxide-trihydroxyindole procedure for the analysis of catecholamines. Journal of Pharmacology and Experimental Therapeutics 138(3): 360-375.

Bobrovskaya, L., Damanhuri, H.A., Ong, L.K., Schneider, J.J., Dickson, P.W., Dunkley, P.R. \& Goodchild, A.K. 2010. Signal transduction pathways and tyrosine hydroxylase regulation in the adrenal medulla following glucoprivation: An in vivo analysis. Neurochemistry International 57(2): 162-167.

Bobrovskaya, L., Gelain, D.P., Gilligan, C., Dickson, P.W. \& Dunkley, P.R. 2007. PACAP stimulates the sustained phosphorylation of tyrosine hydroxylase at serine 40 . Cellular Signalling 19(6): 1141-1149.

Bobrovskaya, L., Dunkley, P.R. \& Dickson, P.W. 2004. Phosphorylation of Ser19 increases both Ser40 phosphorylation and enzyme activity of tyrosine hydroxylase in intact cells. Journal of Neurochemistry 90(4): 857-864.

Brodows, R.G., Pi-Sunyer, F.X. \& Campbell, R.G. 1975. Sympathetic control of hepatic glycogenolysis during glucopenia in man. Metabolism: Clinical and Experimental 24(5): 617-624.

Campbell, D.G., Hardie, D.G. \& Vulliet, P.R. 1986. Identification of four phosphorylation sites in the N-terminal region of tyrosine hydroxylase. Journal of Biological Chemistry 261(23): 10489-10492.

Doggrell, S.A. \& Brown, L. 1998. Rat models of hypertension, cardiac hypertrophy and failure. Cardiovascular Research 39(1):89-105.

Dronjak, S., Jezova, D. \& Kvetnansky, R. 2004. Different effects of novel stressors on sympathoadrenal system activation 
in rats exposed to long-term immobilization. Annals of the New York Academy of Sciences 1018(1): 113-123.

Dunkley, P.R., Bobrovskaya, L., Graham, M.E., Von NagyFelsobuki, E.I. \& Dickson, P.W. 2004. Tyrosine hydroxylase phosphorylation: Regulation and consequences. Journal of Neurochemistry 91(5): 1025-1043.

Eliasson, K., Hjemdahl, P. \& Kahan, T. 1983. Circulatory and sympatho-adrenal responses to stress in borderline and established hypertension. Journal of Hypertension 1(2): 131-139.

Esler, M. 2011. The sympathetic nervous system through the ages: From Thomas Willis to resistant hypertension. Experimental Physiology 96(7): 611-622.

Goldstein, D.S., Breier, A., Wolkowitz, O.M., Pickar, D. \& Lenders, J.W. 1992. Plasma levels of catecholamines and corticotrophin during acute glucopenia induced by 2-deoxyD-glucose in normal man. Clinical Autonomic Research 2(6): 359-366.

Gordon, S.L., Bobrovskaya, L., Dunkley, P.R. \& Dickson, P.W. 2009. Differential regulation of human tyrosine hydroxylase isoforms 1 and 2 in situ: Isoform 2 is not phosphorylated at Ser35. Biochimica et Biophysica Acta 1793(12): 1860-1867.

Grobecker, H., Saavedra, J.M. \& Weise, V.K. 1982. Biosynthetic enzyme activities and catecholamines in adrenal glands of genetic and experimental hypertensive rats. Circulation Research 50(5): 742-746.

Guo, X. \& Wakade, A.R. 1994. Differential secretion of catecholamines in response to peptidergic and cholinergic transmitters in rat adrenals. Journal of Physiology 475(3): 539-545.

Haycock, J.W. 1996. Short- and long-term regulation of tyrosine hydroxylase in chromaffin cells by VIP and PACAP. Annals of the New York Academy of Sciences 805(1): 219-230.

Haycock, J.W. 1993. Multiple signaling pathways in bovine chromaffin cells regulate tyrosine hydroxylase phosphorylation at Ser19, Ser31, and Ser40. Neurochemical Research 18(1): 15-26.

Haycock, J.W. \& Wakade, A.R. 1992. Activation and multiplesite phosphorylation of tyrosine hydroxylase in perfused rat adrenal glands. Journal of Neurochemistry 58(1): 57-64.

Haycock, J.W., Ahn, N.G., Cobb, M.H. \& Krebs, E.G. 1992. ERK1 and ERK2, two microtubule-associated protein 2 kinases, mediate the phosphorylation of tyrosine hydroxylase at serine-31 in situ. Proceedings of the National Academy of Sciences of the United States of America 89(6): 2365-2369.

Komanicky, P., Reiss, D.L., Dale, S.L. \& Melby, J.C. 1982. Role of adrenal steroidogenesis in etiology of hypertension in the spontaneously hypertensive rat. Endocrinology 111(1): 219-224.

Kumai, T., Tanaka, M., Watanabe, M. \& Kobayashi, S. 1994. Elevated tyrosine hydroxylase mRNA levels in the adrenal medulla of spontaneously hypertensive rats. Japanese Journal of Pharmacology 65(4): 367-369.

Lambert, G.W., Eisenhofer, G., Cox, H.S., Horne, M., Kalff, V., Kelly, M., Jennings, G.L. \& Esler, M.D. 1991. Direct determination of homovanillic acid release from the human brain, an indicator of central dopaminergic activity. Life Sciences 49(15): 1061-1072.

Matsunaga, H., Iguchi, A., Yatomi, A., Uemura, K., Miura, H., Gotoh, M., Mano, T. \& Sakamoto, N. 1989. The relative importance of nervous system and hormones to the 2-deoxy-D-glucose-induced hyperglycemia in fed rats. Endocrinology 124(3): 1259-1264.

McCarty, R., Kvetnansky, R., Lake, C.R., Thoa, N.B. \& Kopin, I.J. 1978. Sympatho-adrenal activity of SHR and WKY rats during recovery from forced immobilization. Physiology \& Behavior 21(6): 951-955.

Mirsky, I.A., Kaplan, S.M., Podore, C.J. \& Broh-Kahn, R.H. 1950. The insulin tolerance test in patients with essential hypertension. Journal of Clinical Investigation 29(3): 297301.

Moura, E., Pinho Costa, P.M., Moura, D., Guimarães, S. \& Vieira-Coelho, M.A. 2005. Decreased tyrosine hydroxylase activity in the adrenals of spontaneously hypertensive rats. Life Sciences 76(25): 2953-2964.

Mozaffari, M.S., Roysommuti, S. \& Wyss, J.M. 1996. Contribution of the sympathetic nervous system to hypertensive response to insulin excess in spontaneously hypertensive rats. Journal of Cardiovascular Pharmacology 27(4): 539-544.

Niijima, A. 1975. The effect of 2-deoxy-D-glucose and D-glucose on the efferent discharge rate of sympathetic nerves. Journal of Physiology 251(1): 231-243.

Norman Jr., R.A. \& Dzielak, D.J., 1986. Spontaneous hypertension is primarily the result of sympathetic overactivity and immunologic dysfunction. Proceedings of the Society for Experimental Biology and Medicine 182(4): 448-453.

Okamoto, K. \& Aoki, K. 1963. Development of a strain of spontaneously hypertensive rats. Japanese Circulation Journal 27(3): 282-293.

Reinhard Jr., J.F., Smith, G.K. \& Nichol, C.A. 1986. A rapid and sensitive assay for tyrosine-3-monooxygenase based upon the release of ${ }^{3} \mathrm{H}_{2} \mathrm{O}$ and adsorption of $\left[{ }^{3} \mathrm{H}\right]$-tyrosine by charcoal. Life Sciences 39(23): 2185-2189.

Scheurink, A. \& Ritter, S. 1993. Sympathoadrenal responses to glucoprivation and lipoprivation in rats. Physiology \& Behavior 53(5): 995-1000.

Segura-Chama, P., Rivera-Cerecedo, C.V., Gonzalez-Ramirez, R., Felix, R., Hernandez-Guijo, J.M. \& Hernandez-Cruz, A. 2012. A typical $\mathrm{Ca}^{2+}$ currents in chromaffin cells from SHR and WKY rat strains result from the deficient expression of a splice variant of the alpha1D $\mathrm{Ca}^{2+}$ channel. American Journal of Physiology-Heart and Circulatory Physiology 302(2): H467-H478.

Vollmer, R.R., Balcita, J.J., Sved, A.F. \& Edwards, D.J. 1997. Adrenal epinephrine and norepinephrine release to hypoglycemia measured by microdialysis in conscious rats. American Journal of Physiology-Regulatory, Integrative and Comparative Physiology 273(5): R1758-R1763.

Wexler, B.C. 1980. Transplantation of pituitary and adrenal glands of spontaneously hypertensive rats into hypophysectomized or adrenalectomized, normotensive 
Sprague-Dawley rats. British Journal of Experimental Pathology 61(4): 429-439.

Yamaguchi, N. 1992. Sympathoadrenal system in neuroendocrine control of glucose: Mechanisms involved in the liver, pancreas, and adrenal gland under hemorrhagic and hypoglycemic stress. Canadian Journal of Physiology and Pharmacology 70(2): 167-206.

Zhang, W. \& Thorén, P. 1998. Hyper-responsiveness of adrenal sympathetic nerve activity in spontaneously hypertensive rats to ganglionic blockade, mental stress and neuronglucopenia. Pflügers Archiv - European Journal of Physiology 437(1): 56-60.

Hanafi Ahmad Damanhuri*

Department of Biochemistry

Faculty of Medicine

Universiti Kebangsaan Malaysia Medical Centre

Jalan Yaacob Latif, Bandar Tun Razak

56000 Kuala Lumpur, Federal Territory

Malaysia
Peter Robert Dunkley

School of Biomedical Sciences and Pharmacy

The University of Newcastle, Callaghan

New South Wales, 2308

Australia

Ann Kathleen Goodchild

Department of Biomedical Sciences

Faculty of Medicine and Health Sciences

Macquarie University

Sydney, New South Wales 2109

Australia

*Corresponding author; email: hanafi.damanhuri@ppukm.ukm. edu.my

Received: 11 March 2020

Accepted: 17 July 2020 